\title{
COVID- 19 and Economic Loss of First Phase of (21- Day) Lockdown in India
}

Tiken Das ${ }^{\dagger *}$ and Diganta Das ${ }^{*}$

\section{Abstract}

To curb Covid-19 spread, Prime Minister Narendra Modi has announced a 21-day nationwide lockdown on 23 March 2020. The present study makes an attempt to estimate the state-wise and economic activity-wise economic loss of 21- day lockdown in India. The data on Net State Value Added (NSVA) by economic activity was collected for five years from the Reserve Bank of India. It was found that the percentage of the daily loss of Net State Value Added (NSVA) was considerably higher for the states of Chandigarh, Delhi and Karnataka. The manufacturing sector was expected to be the highest loser, followed by real estate, ownership of dwelling and professional services. In absolute terms, the loss was prominent in Maharashtra, Tamil Nadu and Karnataka. It is worth mentioning here that what could be the magnitude of the impact of a complete social and economic shutdown may not be easy to estimate, but it is likely to be far more severe.

Keywords: COVID- 19; Lockdown; Economic Loss; Net State Value Added; Economic Activity; Manufacturing Sector; India

\footnotetext{
${ }^{\dagger}$ Assistant Professor, Department of Economics, Nowgong College AT Rd, Christianpatty, Nagaon, Assam, 782001 ${ }^{*}$ Corresponding Author, Email: tikenhyd@gmail.com

¥Ph.D Scholar, Centre for Studies in Society and Development, Central University of Gujarat, Sector-29, Gandhinagar: 382030, Email: diganta253@gmail.com

(C) 2020 Das \& Das. This is an Open Access article distributed under the terms of the Creative Commons Attribution License (http://creativecommons.org/licenses/by/2.0), which permits unrestricted use, distribution, and reproduction in any medium, provided the original work is properly cited.
} 


\section{Introduction}

Coronavirus disease 2019 (COVID-19) is an infectious disease caused by severe acute respiratory syndrome coronavirus 2 (World Health Organization, 2020). The disease was first identified in December 2019 in Wuhan, the capital of China's Hubei province, and has since spread globally, resulting in the ongoing 201920 coronavirus pandemic (World Health Organization, 2020a). As of 14 April 2020, more than 1.91 million cases COVID-19 have been reported in 210 countries and territories, resulting in more than 119,000 deaths (Center for Systems Science and Engineering, 2020). More than 449,000 people have recovered, although there may be a possibility of reinfection (Center for Systems Science and Engineering, 2020). In India, as of 12 April 2020, the Ministry of Health and Family Welfare has confirmed a total of 10,363 cases, out of which 1,036 recovered but 339 faced death. Prime Minister Narendra Modi has announced a 21-day nationwide lockdown on 23rd March 2020 to prevent the spread of COVID-19, since social distancing has proven to be one of the most effective tools in curbing its spread. The impact on the economy has been severed as no economic activity has taken place for 21 days, except for essential services and public administration. It was argued that, if the 21-day long national lockdown leads to $80 \%$ production loss, the economy will take a hit of INR 350000400000 million on a daily basis shaving off INR $6000.3-7000.2$ million cumulatively ("21-Day Lockdown", 2020). India's GDP growth could fall below $5 \%$ in the fiscal year 2021, if policy action is not taken urgently, according to the Confederation of Indian Industry (Mukherji, 2020).

Along with the growth hit and poor tax collections, the fiscal deficit for 2021 to balloon by over $1 \%$ of GDP (Wadhwa, 2020). Many warn it may result in a significant number of people dying due to hunger and poverty arising out of the economic impact of the lockdown (Bhasin, 2020). According to a survey by the Centre for Monitoring Indian Economy, India's unemployment rate could have climbed to more than $20 \%$ ( $N a g, 2020$ ). As many as $92.5 \%$ of labours have already lost one to three weeks of work, according to a rapid assessment survey by Jan Sahas (Kapur, 2020). The small-scale sector has suffered more than the large-scale sector, as these businesses work with a limited amount of working capital and, as their sales have declined, they will exhaust it (Kumar, 2020). Within these contexts, the present study attempts to estimate the state-wise and economic activity-wise economic loss of 21- day lockdown in India.

The rest of the paper is arranged as follows. The data and strategy for quantifying losses are covered in the second section. The third section describes the state and economic activity-wise loss in 21- day lockdown period. The conclusion is sketched in the final section.

\section{Data Source and Strategy for Quantifying Loss}

The data on Net State Value Added (NSVA) by economic activity (at basic price 2011-12, at current prices) was collected for five years (2014-2015, 2015-2016, 2016-2017, 2017-2018 and 2018-2019) from the Reserve Bank of India (RBI). NSVA is defined as a State Net Domestic Product plus subsidies on products minus taxes, and NSVA generally is a better indicator for analytics (Mishra, 2020). After calculating the average of the five years NSVA across states and economic activities, the study estimated the value of NSVA per day, because the study accessed the impact of 21-day shutdown period. While estimating the economic loss of 21- day lockdown, the present study included seven sectors - mining and quarrying; manufacturing; construction; trade, repair, hotels and restaurants; transport, storage, communication \& services related to broadcasting; financial services; real estate, ownership of dwelling \& professional services, which were complete shutdown or near-complete shutdown. No concrete estimates for agriculture, forestry and fishing can be made at the moment, because the impact on agriculture, which is seasonal in nature, cannot be ascertained exactly (Bhasin, 2020; Mishra, 2020). Besides, electricity, gas, water supply and other utilities; and public 
administration, defence and other services have continued as earlier, so they may not witness any loss of economic activity (Mishra, 2020). It is assumed that a few functional sub-sectors may have a nullifying effect on the disruptions in excluded sectors like agriculture, public administration which cannot be quantified accurately (Mishra, 2020).

\section{State and Economic Activity-Wise Loss in 21- Day Lockdown Period}

Estimates reveal that in Chandigarh and Delhi, out of a total per day value of NSVA, both the states are expected to occur loss of $83 \%$, every day (Figure 1). Karnataka incurs a second highest loss of $78 \%$, as against $77 \%$ in Uttarakhand. In the case of Goa and Maharashtra, the share of loss is $76 \%$ each. Likewise, the share of loss is $61 \%$ in Assam and Odisha, 26\% in Arunachal Pradesh and 29\% in Mizoram.

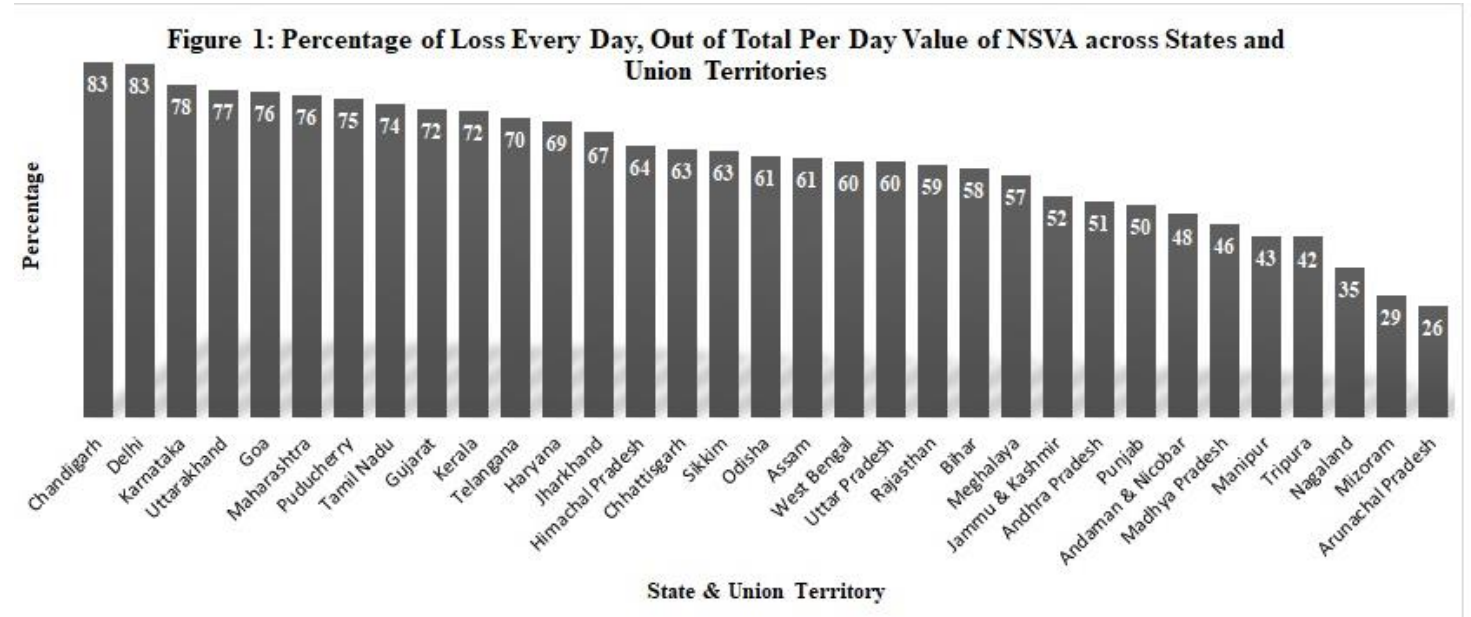

Source: Author's estimation based on the NSVA data collected from RBI for five years: 2014-2015, 2015-2016, 2016-2017, 2017-2018 and 2018-2019

The Indian economy is expected to lose around INR 4576.0 billion during the 21- day nationwide lockdown period (Table 1). The sector that is hugely impacted is manufacturing (loss of INR 1058.2 billion), as against real estate, ownership of dwelling \& professional services (loss of INR 1026.2 billion). Kumar (2020) argued that the impact on the manufacturing sector will be quite large because people are required to go to their workplaces and that has been curtailed due to the lockdown. As far as state-wise loss is concerned, Maharashtra has emerged as the highest loser with INR 697.3 billion, while Tamil Nadu states in second place (INR 447.5 billion). Among all states and union territories, Karnataka ranks third with a loss of INR 430 billion during the 21- day lockdown period. It is also apparent from Table 1 that among all states and union territories, the loss of manufacturing, and trade, repair, hotels and restaurant sectors are perhaps highest in Maharashtra (INR 193.2 billion and INR 93.2 billion, respectively). As Table 1 reflects, Gujarat is the second-most loser state in the manufacturing sector after Maharashtra with INR 145.6 billion.

Further, the loss of real estate, ownership of dwelling \& professional services is highest with INR 185.2 billion in Karnataka, whereas it is INR 165.4 billion in Maharashtra. Except for the state of Assam, all other North Eastern States (NES) have incurred minimal loss with the range of INR 2.5 to INR 8.0 billion ( Table 1). It can also be observed in Figure 1 that, except for Assam, Sikkim and Meghalaya, the percentage of per day loss of NSVA is relatively low for the remaining NES. Again, the percentage of per day NSVA loss has been observed to be comparatively smaller in largest states like Andhra Pradesh, Bihar, Madhya Pradesh and Punjab (Figure 1). As Table 1 shows that, the 
states of Andhra Pradesh, Bihar, Madhya Pradesh and Punjab have contributed relatively a smaller amount to the total loss of the economy. Also, in these states, a significant portion of losses is from manufacturing and trade, repair, hotels and restaurants sectors (Table 1). The contribution of Goa and Puducherry on the total loss of the economy is only INR 19.7 (0.4\%) and INR 9.9 billion (0.2\%), respectively, which can be possible because of their smaller economy size. However, their percentage of per day NSVA loss is found to be $76 \%$ (fifth position) and 75\% (seventh position), respectively and this reflects the greater dependence on manufacturing sector.

\begin{tabular}{|c|c|c|c|c|c|c|c|c|}
\hline State/UT & M\&Q & $\mathbf{M}$ & $\mathbf{C}$ & TRH\&R & TSC\&B & FS & REOPS & Total Loss \\
\hline Andhra Pradesh & 9.0 & 27.9 & 25.9 & 27.0 & 29.4 & 12.0 & 26.7 & 157.8 \\
\hline Arunachal Pradesh & 0.0 & 0.3 & 1.0 & 0.4 & 0.2 & 0.2 & 0.3 & 2.5 \\
\hline Assam & 11.0 & 12.1 & 9.1 & 17.1 & 6.0 & 3.4 & 6.6 & 65.3 \\
\hline Bihar & 1.3 & 14.6 & 18.2 & 43.1 & 17.5 & 7.5 & 19.5 & 121.6 \\
\hline Chhattisgarh & 11.2 & 19.2 & 15.6 & 8.8 & 5.2 & 5.3 & 14.2 & 79.5 \\
\hline Goa & 0.3 & 12.1 & 1.0 & 1.9 & 0.8 & 1.4 & 2.1 & 19.7 \\
\hline Gujarat & 16.4 & 145.6 & 30.4 & 59.2 & 23.5 & 28.1 & 26.3 & 329.4 \\
\hline Haryana & 0.3 & 41.4 & 21.4 & 30.4 & 13.9 & 10.3 & 39.9 & 157.6 \\
\hline Himachal Pradesh & 0.2 & 16.7 & 4.6 & 3.6 & 2.6 & 2.6 & 6.2 & 36.5 \\
\hline Jammu \& Kashmir & 0.3 & 4.8 & 4.8 & 5.2 & 3.2 & 2.4 & 6.0 & 26.6 \\
\hline Jharkhand & 9.4 & 18.3 & 9.7 & 13.3 & 8.0 & 3.6 & 9.5 & 71.7 \\
\hline Karnataka & 4.0 & 79.0 & 34.8 & 64.7 & 32.6 & 30.1 & 185.2 & 430.4 \\
\hline Kerala & 1.9 & 24.8 & 38.7 & 51.7 & 20.8 & 12.3 & 38.9 & 189.1 \\
\hline Madhya Pradesh & 11.7 & 25.0 & 25.5 & 34.3 & 17.5 & 12.5 & 15.0 & 141.3 \\
\hline Maharashtra & 31.3 & 193.2 & 58.4 & 93.2 & 52.3 & 103.4 & 165.4 & 697.3 \\
\hline Manipur & -- & 0.3 & 1.1 & 1.4 & 0.6 & 0.2 & 0.8 & 4.4 \\
\hline Meghalaya & 0.7 & 1.0 & 1.0 & 2.7 & 0.7 & 0.4 & 0.7 & 7.2 \\
\hline Mizoram & 0.1 & 0.1 & 0.8 & 0.8 & 0.3 & 0.2 & 0.3 & 2.3 \\
\hline Nagaland & 0.1 & 0.1 & 0.9 & 1.0 & 0.4 & 0.3 & 0.7 & 3.5 \\
\hline Odisha & 13.9 & 23.1 & 13.7 & 19.0 & 11.5 & 7.4 & 12.9 & 101.4 \\
\hline Punjab & 0.4 & 26.6 & 13.1 & 21.9 & 9.6 & 10.7 & 17.3 & 99.6 \\
\hline Rajasthan & 26.5 & 38.5 & 33.4 & 46.0 & 20.9 & 12.2 & 40.3 & 217.6 \\
\hline Sikkim & 0.0 & 4.0 & 0.5 & 0.5 & 0.2 & 0.2 & 0.3 & 5.7 \\
\hline Tamil Nadu & 2.5 & 115.8 & 70.6 & 77.4 & 39.6 & 35.6 & 105.9 & 447.5 \\
\hline Telangana & 9.8 & 39.9 & 16.1 & 51.4 & 21.3 & 20.7 & 64.7 & 223.9 \\
\hline Tripura & 2.1 & 0.7 & 1.1 & 1.8 & 0.6 & 0.7 & 1.0 & 8.0 \\
\hline Uttarakhand & 1.3 & 34.1 & 7.3 & 11.9 & 5.8 & 2.5 & 3.9 & 66.8 \\
\hline Uttar Pradesh & 7.2 & 71.7 & 65.9 & 59.6 & 43.8 & 23.3 & 83.4 & 354.9 \\
\hline West Bengal & 4.1 & 46.0 & 32.1 & 70.4 & 25.6 & 22.7 & 51.2 & 252.1 \\
\hline Andaman \& Nicobar & 0.1 & 0.0 & 0.4 & 0.3 & 0.3 & 0.1 & 0.3 & 1.5 \\
\hline Chandigarh & 0.0 & 0.6 & 0.7 & 5.3 & 0.8 & 2.1 & 2.4 & 11.8 \\
\hline Delhi & 4.1 & 16.9 & 13.0 & 36.9 & 39.7 & 44.4 & 76.8 & 231.8 \\
\hline Puducherry & 0.2 & 4.0 & 1.9 & 1.3 & 0.5 & 0.5 & 1.5 & 9.9 \\
\hline Grand Total & 181.2 & 1058.2 & 572.5 & 863.1 & 455.5 & 419.3 & 1026.2 & 4576.0 \\
\hline
\end{tabular}

Source: Author's estimation based on the NSVA data collected from RBI for five years: 20142015, 2015-2016, 2016-2017, 2017-2018 and 2018-2019

Note: $M \& Q=$ Mining and Quarrying; $M=$ Manufacturing; $C=$ Construction; TRH\&R= Trade, Repair, Hotels and Restaurants; TSC\&B= Transport, Storage, Communication \& Services related to Broadcasting; FS= Financial Services; REOPS= Real Estate, Ownership of Dwelling \& Professional Services 


\section{Conclusion}

As the coronavirus cases in India climb, imposing a lockdown on 1.3 billion people was always going to be challenging. The daily loss of NSVA is considerably higher for the states of Chandigarh, Delhi and Karnataka. The manufacturing sector is expected to be the highest loser, followed by real estate, ownership of dwelling \& professional services. In absolute terms, the loss is prominent in Maharashtra, Tamil Nadu and Karnataka. Except for the state of Assam, all other NES have incurred minimal losses. The study shows that the percentage of daily NSVA loss is comparatively lower in larger states like - Andhra Pradesh, Bihar, Madhya Pradesh and Punjab. It is worth mentioning here that what could be the magnitude of the impact of a complete social and economic shutdown may not be easy to estimate, but it is likely to be far more severe. Since each sector has its own dynamics and different cycles, therefore, the full impact can be felt beyond a few months (e.g. six months to one year).

\section{References}

21-day lockdown care ratings predicts Rs 7.2 lakh crore impact on economy. (2020, March 25). Retrieved on 25 March 2020 from, https://www.businesstoday.in/current/econom y-politics/21-day-lockdown-care-ratingspredicts-rs-72-lakh-crore-impact-oneconomy/story/399250.html

Bhasin, K. (2020). Govt can cushion economic impact of the lockdown. Retrieved 30 March 2020 from, https://www.livemint.com/news/india/govtcan-cushion-economic-impact-of-the-lockdown11585157317394.html

Center for Systems Science and Engineering. (2020). Coronavirus COVID-19 global cases by the Center for Systems Science and Engineering at Johns Hopkins University. Retrieved 15 April 2020 from, https://gisanddata.maps.arcgis.com/apps/opsd ashboard/index.html\#/bda7594740fd40299423 467b48e9ecf6

Kapur, M. (2020). Charted: lockdown is only the beginning of misery for India's migrant labourers. Retrieved15 April 2020 from, https://qz.com/india/1833814/coronaviruslockdown-hits-india-migrant-workers-pay-foodsupply/

Kumar, A. (2020). Impact of Covid-19 and what needs to be done. Economy and Political Weekly, 55 (14), 20-25.

Mishra, H. H. (2020, March 28). Coronavirus in India: COVID-19 lockdown may cost the economy Rs 8.76 lakh crore; here's how. Business Today. Retrieved 15 April 2020 from, https://www.businesstoday.in/opinion/column s/coronavirus-in-india-covid-19-india-lockdowneconomy-cost-gdp-gva-nationwideshutdown/story/399477.html

Mukherji, B. (2020). Coronavirus impact: Indian industry seeks relief measures to aid economy. Retrieved15 April 2020 from, https://www.livemint.com/companies/news/co ronavirus-impact-indian-industry-seeks-reliefmeasures-to-aid-economy11584904435575.html

Nag, A. (2020). India jobless rate swells above $23 \%$ amid coronavirus lockdown, survey shows. The Economic Times. Retrieved 15 April 2020 from, https://economictimes.indiatimes.com/jobs/ind ia-jobless-rate-swells-above-23-amidcoronavirus-lockdown-surveyshows/articleshow/75023958.cms

Wadhwa, P. (2020). With 75\% economy under lockdown, analysts see sharp fall in GDP. Business Standard. Retrieved 15 April 2020 from, https://www.businessstandard.com/article/economy-policy/with-75economy-under-lockdown-analysts-see-sharpfall-in-gdp-120032600231_1.html

World Health Organization. (2020). Coronavirus disease 2019 (COVID-19): prevention \& treatment. Retrieved 15 April 2020 from, https://www.who.int/docs/defaultsource/coronaviruse/situationreports/20200222-sitrep-33-covid-19.pdf World Health Organization. (2020a). Naming the coronavirus disease (COVID-19) and the virus that causes it. Retrieved 15 April 2020 
from,

https://www.who.int/emergencies/diseases/no vel-coronavirus-2019/technical- guidance/naming-the-coronavirus-disease-

(covid-2019)-and-the-virus-that-causes-it 